\title{
Changes in Water Surface Area of the Lake in the Steppe Region of Mongolia: A Case Study of Ugii Nuur Lake, Central Mongolia
}

\author{
Erdenesukh Sumiya ${ }^{1}\left(\mathbb{D}\right.$, Batsuren Dorjsuren ${ }^{2, *(\mathbb{D})}$, Denghua Yan ${ }^{3, *}$, Sandelger Dorligjav ${ }^{1}$, \\ Hao Wang ${ }^{3}$, Altanbold Enkhbold ${ }^{1}\left(\mathbb{D}\right.$, Baisha Weng ${ }^{3}{ }^{(D}$, Tianlin Qin ${ }^{3}{ }^{(D}$, Kun Wang ${ }^{3}$, \\ Tuvshin Gerelmaa ${ }^{1}$, Oyunbaatar Dambaravjaa ${ }^{4}$, Wuxia Bi ${ }^{3,5} \mathbb{D}$, Yuheng Yang ${ }^{3}{ }^{\mathbb{D}}$, \\ Byambabayar Ganbold $^{1}\left(\mathbb{D}\right.$, Mohammed Gedefaw ${ }^{6,7} \mathbb{D}$, Asaminew Abiyu ${ }^{6} \mathbb{D}$ and \\ Abel Girma ${ }^{6,7}$ (D)
}

1 Department of Geography, Division of Natural Sciences, School of Arts \& Sciences, National University of Mongolia, Ulaanbaatar 210646, Mongolia; erdenesukh@num.edu.mn (E.S.); d.sandelger@num.edu.mn (S.D.); altanbold@num.edu.mn (A.E.); tuvshin4097@gmail.com (T.G.); byambabayar@num.edu.mn (B.G.)

2 Department of Environment and Forest Engineering, School of Engineering and Applied Sciences, National University of Mongolia, Ulaanbaatar 210646, Mongolia

3 State Key Laboratory of Simulation and Regulation of Water Cycle in River Basin, Water Resources Department, China Institute of Water Resources and Hydropower Research (IWHR), Beijing 100038, China; Wanghao@iwhr.com (H.W.); baishaweng@163.com (B.W.); qintl@iwhr.com (T.Q.); pingguo88wangkun@163.com (K.W.); biwuxia_1992@163.com (W.B.); 1109080115@cau.edu.cn (Y.Y.)

4 Surface Water Research Department, Information and Research Institute of Meteorology, Hydrology, and Environment, Ulaanbaatar 210646, Mongolia; oytetuarel@yahoo.com

5 College of Hydrology and Water Resources, Hohai University, Nanjing 210098, China

6 College of Environmental Science and Engineering, Donghua University, Shanghai 201620, China; Mohammedgedefaw@gmail.com (M.G.); Asaminewab@yahoo.com (A.A.); Abelethiopia@yahoo.com (A.G.)

7 Department of Natural Resource Management, University of Gondar, Gondar 196, Ethiopia

* Correspondence: batsuren@seas.num.edu.mn (B.D.); yandh@iwhr.com (D.Y.); Tel.: +976-77307730-3208 (B.D.); +86-10-68781976 (D.Y.)

Received: 27 February 2020; Accepted: 11 May 2020; Published: 21 May 2020

\begin{abstract}
The Ugii Nuur Lake is not only one of the small hydrologically closed lakes located in the Orkhon River Basin in Central Mongolia but also the most vulnerable area for global climate change. Therefore, this study aims to investigate the impacts of recent global climate change on the water surface area. The data we analyzed were various measured hydro-meteorological variables of the lake basin and the lake surface area, which was estimated from Landsat series satellite data from 1986 to 2018. The methods we used were Mann-Kendall (MK), Innovative trend analysis method (ITAM), Sen's slope estimator test, correlation, and regression analysis. The variation of lake water surface area has a strong positive correlation with the change of the lake water level $(r=0.95)$. The Mann-Kendall trend analysis has indicated that under a significant decrease in total annual precipitation $(Z=-0.902)$ and inflow river discharge $(Z=-5.392)$ and a considerable increase in total annual evaporation $(Z=4.385)$ and annual average air temperature $(Z=4.595)$, the surface area of the Ugii Nuur Lake has decreased sharply $(Z=-6.021)$. The total annual evaporation $(r=-0.64)$ and inflow river discharge $(r=0.67)$ were the essential hydro-meteorological factors affecting the surface area of the Ugii Nuur Lake. The lake surface area decreased by $13.5 \%$ in 2018 compared with 1986. In the near future, it is vital to conduct scientific studies considering the volume of lake water, groundwater, and the anthropogenic impact.
\end{abstract}

Keywords: water surface area; air temperature; precipitation; river discharge; evaporation; Mongolia 


\section{Introduction}

Global climate change has apparent impacts on the environmental and hydrological systems [1]. It is possible to determine the impacts by temporal variability in the surface water resources at the center of the mainland [2] especially over the semi-arid steppe, Gobi, and desert region of Central Asia [3]. Thus, it has become an interesting issue to study the change of water resources in those regions since there is low total annual precipitation and few surface water distributions [4,5]. Those regions include Mongolia, where the annual average air temperature has increased by $2.2{ }^{\circ} \mathrm{C}$ since the 1940 s, which is three times over-heated than global warming speed. The territory of Mongolia is characterized as semi-arid to arid. Total annual precipitation is $300-400 \mathrm{~mm}$ in the Northern mountainous regions of Mongolia; 150-250 mm in the steppe; 100-150 mm in the steppe desert; and 50-100 $\mathrm{mm}$ in the Gobi Desert. About $80 \%$ to $90 \%$ of total annual precipitation falls in the warm season, which is from April to September [6]. Thus, the Gobi, desert, and steppe regions of Mongolia are considered vulnerable for global climate change $[7,8]$. Monitoring surface water ecosystems in this region may be necessary for detecting the effects of global climate change. One of these regions is the Ugii Nuur Lake basin, which is a representative location for the dry steppe region of Mongolia and the natural ecosystem influenced by desertification and dryness (Figure 1) [9-11]. The Ugii Nuur Lake has been registered under the Ramsar Convention for the Protection of Wetlands of International Importance since 1998; also, it is a famous tourist destination in Mongolia. Meanwhile, the Ugii Nuur Lake basin is an ideal location to study Holocene climate evolution in the continental area of the steppe region in Mongolia [12,13].

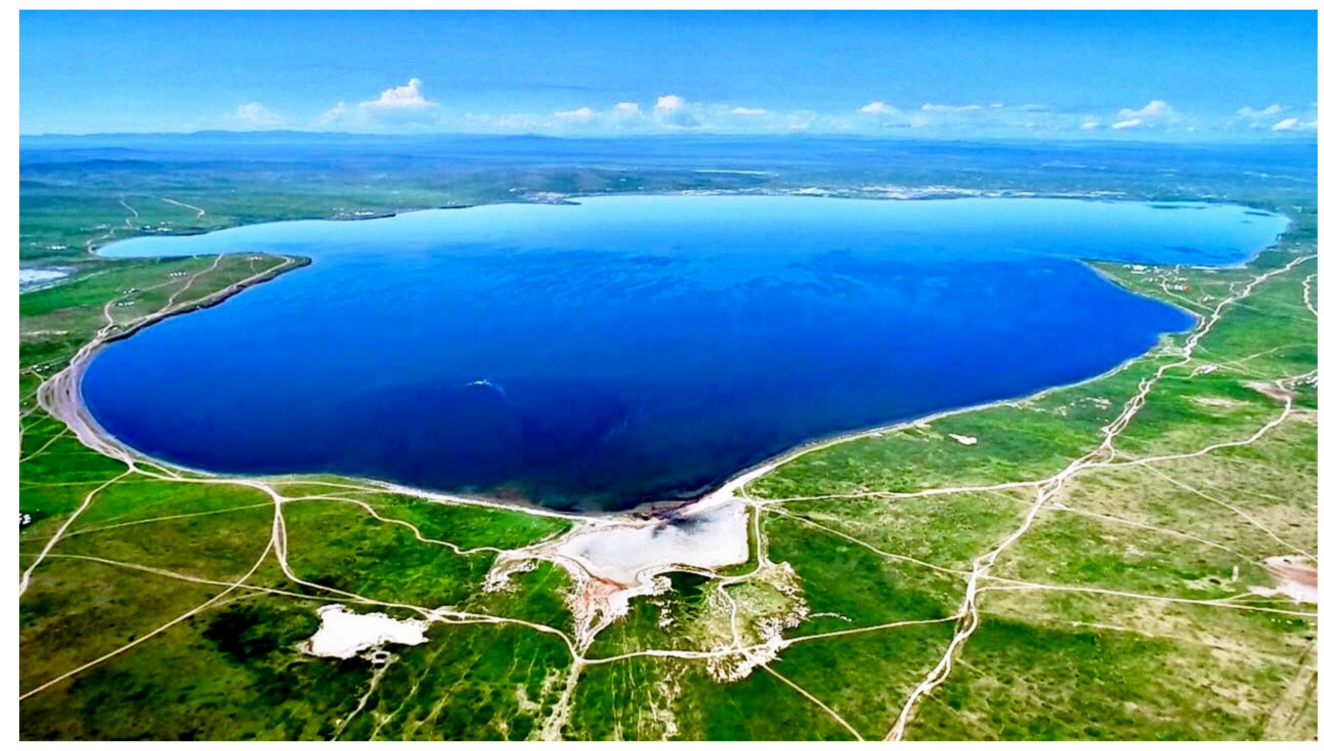

Figure 1. The Ugii Nuur Lake, northwest-facing view of the landscape in 2018. Photo by Uuganbat Tumur.

Scientists have implemented several local surveys in the fields of soil, vegetation, and ecology surrounding the Ugii Nuur Lake [14], and have also studied lake morphometric parameters [11,14], geological parameters such as the age of lake sediments, paleoclimate, environmental change, and climate evolution, etc. $[9,10,12,13,15,16]$. The Ugii Nuur Lake Basin belongs to the steppe region of Mongolia with brown steppe soil as a dominant soil type. As for vegetation cover, Stipa, Bidle grass (Cleistogenes), and Agropyron types of grass are the dominant types in the lake basin area [12,14,15]. Jimee [11] considered that the lake formed as a result of the channel meandering processes of the Orkhon river. He also estimated that the surface area of the lake was $5020 \mathrm{~km}^{2}$. The main inflow of the lake is the Khogshin Orkhon river. The water regime of the lake was influenced by the flow regulating the capacity of the Orkhon river. Approximately 50\% of the lake water surface area has a depth of lower than $3 \mathrm{~m}$ [11]. Several studies focused on lake sediments. Pagma et al. [17] determined the interrelation between lake physics and the surrounding climate by taking samples from the borehole 
drilled with a depth of $0.38 \mathrm{~m}$ at the Ugii Nuur Lake bottom. The analysis of the radio-carbon test, which is used for determination of sediment age, shows that the age of the Ugii Nuur Lake would be $2880 \pm 50$ years at a depth of 1.6-2.0 $\mathrm{m}$ [17].

The average elevation above sea level of the lake is not only a vital point of water level measurement but also a tracer of water balance and water surface area of the lake. Different studies present several elevation values of the mean water level of the lake in different periods. The reasons can be concluded as the differences in the methods used, time determined, and climate condition. According to Jimee [11], the elevation of the lake water level was around $1332 \mathrm{~m}$ and $1337 \mathrm{~m}$ above sea level in 1971 and 2000, respectively. Walther, Gegeensuvd [10], Schwanghart, Schütt [13], and Wang et al. [16] stated that elevations of the lake water levels were 1332 m, 1328 m, and 1332 m, respectively. Studies done by the Information and Research Institute of Meteorology, Hydrology, and Environment of Mongolia showed that the mean water level of the lake corresponds to the elevation above sea level was $1335 \mathrm{~m}$ in 2018 [18].

The Ugii Nuur Lake is relatively shallow compared to other lakes in Mongolia, and the Khogshin Orkhon river is the unique surface inflow into the lake. There are few studies related to groundwater and flow, so it has no highlights on the lake water supply $[19,20]$. Satellite images are widely used to investigate water surface area changes [21]. Furthermore, the simple and effective way to study the lake water supply and the regime is to estimate the components of water balance and then compare them with the water surface area of the lake [22,23]. The use of non-parametric Mann-Kendall (MK) testing, correlation, and regression analysis is also suitable for the expression of long-term changes in hydro-meteorological variables $[8,24,25]$. Thus, this study aims to determine the changes in the water surface area of the Ugii Nuur Lake due to recent global climate change based on the water balance components with data obtained from satellite and hydro-weather stations.

\section{Materials and Methods}

\subsection{Study Area}

The Ugii Nuur Lake $\left(47^{\circ} 46^{\prime} \mathrm{N}, 102^{\circ} 44^{\prime} \mathrm{E}\right)$ is located in the Orkhon river basin. The total area of the Orkhon river basin is $132,835 \mathrm{~km}^{2}, 38.2 \%$ of which belongs to the Arkhangai province of Central Mongolia. The lake exists in the Arkhangai province, which is about $350 \mathrm{~km}$ to the west of the capital city Ulaanbaatar (Figure 2) $[10,12,16]$. The lake has fresh water with mineralization of $0.499 \mathrm{~g} \cdot \mathrm{l}^{-1}$, which is one of the biggest steppe lakes in Mongolia. The main surface inflow is the Khogshin Orkhon river, which is one of the tributaries of the Orkhon river. The lake has a width of $7.9 \mathrm{~km}$ from west to east and $5.3 \mathrm{~km}$ from north to south, and the shoreline length is $24.7 \mathrm{~km}$. The surface area of the lake varies between 25.3 to $25.7 \mathrm{~km}^{2}$ with a mean depth of $6.6 \mathrm{~m}$, and the corresponding mean volume is $0.17 \mathrm{~km}^{3}$ [11]. The maximum depth of the lake is observed in the center of the lake, with a value of $15.3 \mathrm{~m}$. The basin area of the lake is $5020 \mathrm{~km}^{2}$ [11].

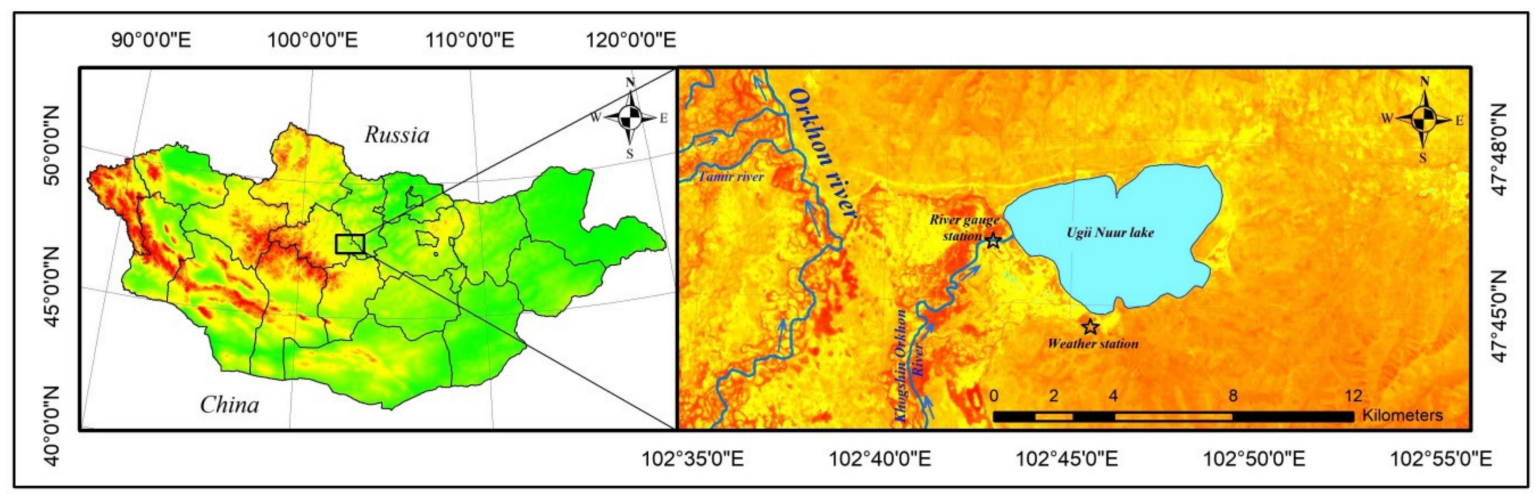

Figure 2. The geographical location of the Ugii Nuur Lake. 


\subsection{Data Sources}

The long-term climate change survey covers data for longer than 30 years, which is recommended by the World Meteorological Organization (WMO). Various types of observations and satellite data from 1986 to 2018 were collected and statistically analyzed. The climate and hydrological data of the Ugii Nuur Lake basin in central Mongolia during 1986 to 2018 were supplied by the Archive and Database center at the National Agency of Meteorology and Environment of Mongolia [26]. The daily and monthly air temperature, wind speed, and precipitation data measured at the Ugii Nuur Weather Station were used for estimating climate factors impacts on lake surface area. Daily river discharge data, measured at the Khogshin Orkhon river station as one of the income components of water balance, has been summarized into total monthly and annual amounts $(\mathrm{mm})$. Then, variations in components of water balance were statistically analyzed and compared with the lake surface area. Water level data of the Ugii Nuur Lake applied for validating the lake surface area was estimated from satellite data. The water surface area of the Ugii Nuur Lake in all Augusts between 1986 and 2012 was calculated by using Normalized Difference Water Index (NDWI) products from Landsat 4 and 5 TM satellite, while data between 2013 and 2018 were obtained by the NDWI products of Landsat 8 OLI satellite [27]. NDWI is an approach to determine water bodies using remotely sensed digital data based on reflected near-infrared radiation and visible green light $[28,29]$.

\subsection{Methods}

The lake water surface images were obtained and calculated by different multi-spectral bands of Landsat satellites. The lake area was calculated by using NDWI in the downloaded images. Analysis of long-term trends in both the observed and adjusted data was done by using the Mann-Kendall test, with linear changes in the data represented by Kendall-Theil Robust Lines. The non-parametric Mann-Kendall (MK) test has been applied in studies to detect the trends in hydro-meteorological observations that do not need the normal distribution of data points. This study used the MK test method to detect the trends in climate and components of water balance time-series data. For evaluating the reliability of MK, the results were compared with the Innovative trend analysis method (ITAM) and Sen's slope estimator test. Besides, time-series data for annual average air temperature, total annual precipitation, total annual river discharge, total annual evaporation, and water surface area were investigated by statistical analysis. Significance levels at $10 \%, 5 \%$, and $1 \%$ were taken to assess the time-series data for climate and river discharge by MK, ITAM, and Sen's slope estimator method.

\subsubsection{Lake Surface Area Calculation}

The lake water surface mapping with multi-spectral remote-sensing images is based on the difference of the absorption and reflection of light between the water and other features in different frequency bands. As reflections from the water of the visible to infrared bands are gradually weakened, the surface water on an image can be delineated with the NDWI indices by the contrast of the visible wavelength with the near-infrared and short-wave infrared wavelengths [30,31].

$$
\text { NDWI }=\frac{\text { PGreen }- \text { PNIR }}{\text { PGreen }+ \text { PNIR }}
$$

where PGreen is the green band, PNIR is the near-infrared band of Landsat 4-5 TM and Landsat 8 OLI satellites. Using NDWI, lake surface water was mapped on the 33 images taken at different times by extraction using the Band math tool of ENVI 5.5.3 and ArcGIS. For validating lake water surface area calculated by satellite image, the measured lake water level has been correlated with lake water surface area obtained by NDWI. 


\subsubsection{Mann-Kendall (MK) Analytical Method}

The Mann-Kendal (MK) is a non-parametric statistical test used to detect the trends of hydroclimatic variables. The MK test also shows whether the trend is increasing or decreasing. The strength of the trend depends on the magnitude, sample size, and variations of data series. The trends in the MK test are not significantly affected by the outliers that occurred in the data series since the MK test statistically depends on positive or negative signs. The Mann-Kendall test statistics " $S$ " is then equated as [32]:

$$
\mathrm{S}=\sum_{\mathrm{i}=1}^{\mathrm{n}-1} \sum_{\mathrm{j}=\mathrm{i}+1}^{\mathrm{n}} \operatorname{sgn}\left(\mathrm{x}_{\mathrm{j}}-\mathrm{x}_{\mathrm{i}}\right)
$$

The trend test is applied to $x_{i}$ data values $(i=1,2, \ldots n-1)$ and $x_{j}(j=i+1,2, \ldots n)$. The data value of each $x_{i}$ is used as a reference point to compare with the data value of $x_{j}$ which is given as:

$$
\operatorname{sgn}\left(x_{j}-x_{i}\right)=\left\{\begin{array}{r}
+1 \text { if }\left(x_{j}-x_{i}\right)>0 \\
0 \text { if }\left(x_{j}-x_{i}\right)=0 \\
-1 \text { if }\left(x_{j}-x_{i}\right)<0
\end{array}\right.
$$

where $x_{j}$ and $x_{i}$ are the values in period $j$ and $i$. When the number of data series is greater than or equal to ten $(n \geq 10)$, the MK test is then characterized by a normal distribution with the mean $E(S)=0$ and variance $\operatorname{Var}(\mathrm{S})$ is equated as:

$$
\begin{gathered}
E(S)=0 \\
\operatorname{Var}(S)=\frac{n(n-1)(2 n+5)-\sum_{k=1}^{m} t_{k}\left(t_{k}-1\right)\left(2 t_{k}+5\right)}{18}
\end{gathered}
$$

where $m$ is the number of the tied groups in the time series, and $t_{k}$ is the number of ties in the kth tied group. The test statistics $\mathrm{Z}$ is as follows [33]:

$$
Z=\left\{\begin{array}{l}
\frac{s-1}{\delta} \text { if } S>0 \\
0, \quad \text { if } S=0 \\
\frac{s+1}{\delta} \text { if } S<0
\end{array}\right.
$$

When $\mathrm{Z}$ is greater than zero, it indicates an increasing trend, and when $\mathrm{Z}$ is less than zero, it is a decreasing trend.

In time sequence, the statistics are defined independently:

$$
\mathrm{UF}_{\mathrm{k}}=\frac{\mathrm{d}_{\mathrm{k}}-\mathrm{E}\left(\mathrm{d}_{\mathrm{k}}\right)}{\sqrt{\operatorname{var}\left(\mathrm{d}_{\mathrm{k}}\right)}}(\mathrm{k}=1,2, \ldots, \mathrm{n})
$$

Firstly, given the confidence level $\alpha$, if the $\mathrm{UF}_{\mathrm{k}}>\mathrm{UF}_{\alpha} / 2$, the sequence has a significant trend. Then, the time sequence is arranged in reverse order. According to the equation calculation, while making

$$
\begin{aligned}
& \mathrm{UB}_{\mathrm{k}}=-\mathrm{UF}_{\mathrm{k}} \\
& \mathrm{K}=\mathrm{n}+1-\mathrm{k}
\end{aligned}
$$

Finally, $\mathrm{UB}_{\mathrm{k}}$ and $\mathrm{UF}_{\mathrm{k}}$ were drawn as $\mathrm{UB}$ and $\mathrm{UF}$ curves. Where $\mathrm{UF}_{\mathrm{k}}=0$ and $\mathrm{UF}_{\mathrm{k}}$ is a standard normal distribution. There is an upward trend when it is 0 , while there is a downward trend when it is less than 0 . If a significant level $\alpha$ is given, according to the normal distribution table we get the critical value $t_{0}$ and, if $\mathrm{UF}_{\mathrm{k}}>\mathrm{t}_{0}$, this indicates that there is an obvious change trend in the sequence. If the result is multiplied by -1 , then we get the reverse sequence's statistic $U_{k}$, where $U_{k}=0$. If there is an intersection between the two curves, the intersection is the beginning of the mutation [34]. When the two curves $\mathrm{UF}_{\mathrm{k}}$, and $\mathrm{UF}_{\mathrm{k}}$ intersect and the intersection point is between the confidence lines, then the 
intersection point is the abrupt point. According to the test, if between the confidence lines that were defined from the processing of the data the value "zero" is included, then these values present mean values that are statistically equal. Thus, confidence lines are significant levels [35].

\subsubsection{Innovative Trend Analysis Method (ITAM)}

ITAM has been used in many studies to detect the hydro-meteorological observations, and its accuracy was compared with the results of MK method. The trend indicator is given as:

$$
\boldsymbol{\varphi}=\frac{1}{\mathrm{n}} \sum_{\mathrm{i}=1}^{\mathrm{n}} \frac{10\left(\mathrm{x}_{\mathrm{j}}-\mathrm{x}_{\mathrm{i}}\right)}{\mu}
$$

where $\varphi$ - is the trend indicator, $\mathrm{n}$-is the number of observations in the subseries, $\mathrm{x}_{\mathrm{i}}$-is the data series in the first half subseries class, $x_{j}$-is the data series in the second half subseries class, and $\mu$-is the mean of data series in the first half subseries class [36].

\subsubsection{Sen's Slope Estimator Test}

Sen's slope estimator can be used to discover trends in a univariate time series of hydro-meteorological variables such as runoff series, etc. The slope $Q_{\mathrm{i}}$ between two data points is given by the equation:

$$
Q_{i}=\frac{x_{j}-x_{k}}{j-k}, \text { for } i=1,2, \ldots N
$$

where $x_{j}$ and $x_{k}$ are data points at times $j$ and $(j>k)$, respectively. When there is an only single datum in each time, then $\mathrm{N}=\frac{\mathrm{n}(\mathrm{n}-1)}{2} ; \mathrm{n}$ is a number of time periods. However, if the number of data in each year is more than 1 , then $\mathrm{N}<\frac{\mathrm{n}(\mathrm{n}-1)}{2} ; \mathrm{n}$ is the number of total observations. The $\mathrm{N}$ values of slope estimator are arranged from smallest to biggest. Then, the median of slope $(\beta)$ is computed as:

$$
\beta=\left\{\begin{array}{c}
Q[(\mathrm{~N}+1) / 2] \text { when } N \text { is odd } \\
Q[(\mathrm{~N} / 2)+\mathrm{Q}(\mathrm{N}+2) /(2) /(2)] \text { when } N \text { is even }
\end{array}\right.
$$

The sign of $\beta$ shows whether the trend is increasing or decreasing [37].

2.3.5. Analysis and Estimation of Climate and Hydrological Variables Influencing the Water Surface Area of the Lake

To achieve the aim of this study, various types of climate and hydrological measurement data were taken for statistical calculations, for example, hydro-meteorological variables were statistically analyzed with the change of lake surface area by correlation and regression analysis. Since the temporal change of water balance of the lake is directly related to the change of lake surface area [38], one of the components of water balance or evaporation has been estimated for this analysis.

The primary method for estimating the water balance of the lake is based on the difference between income and outcome water flow of the lake $[23,38,39]$.

$$
\frac{d V}{d t}=P-E+Q-Q^{\prime}
$$

where $\mathrm{dV}$ is the change of lake volume within a given time of period $(\mathrm{dt}), \mathrm{P}$ is the precipitation amount, $\mathrm{E}$ is the evaporation from open surface water of a lake, $\mathrm{Q}$ is the surface inflow to the lake, $\mathrm{Q}^{\prime}$ is the surface outflow from the lake. Notably, the Ugii Nuur Lake does not have an outflowing river.

The supply from groundwater and ground flow is an essential component of the water balance of the lake. However, hydro-geological studies on the Ugii Nuur Lakes are barely carried out. For detecting the relationship between recent global climate change and variations in the lake water surface area, it should consider the precipitation and river discharge as income of the water balance 
equation and the evaporation as the outcome. Since both the precipitation and river inflow were measured around the hydro-weather station, we can estimate the evaporation from the lake surface.

Dalton [40] proposed the physical law for estimating evaporation based on the relation among average daily humidity, air temperature, and wind speed. The equation was updated several times, and the widely used equation was proposed by Penman [41,42]. Gombo [30] divided major Mongolian lakes into three groups with an elevation above mean sea level. Based on the equations mentioned above, the researcher proposed empiric equations for evaporation from the lake surface for each lake groups. Since the Ugii Nuur Lake has an elevation of $1335 \mathrm{~m}$ above the mean sea level, it is suggested to calculate its evaporation by the following equation [43]:

$$
\mathrm{E}=0.32\left(1+0.38 \mathrm{v}_{2}\right)\left(\mathrm{e}_{0}-\mathrm{e}_{2}\right)
$$

where $\mathrm{E}$ is the evaporation $(\mathrm{mm}), \mathrm{v}_{2}$ is the wind speed at $2.0 \mathrm{~m}$ above the ground surface $\left(\mathrm{m} \cdot \mathrm{s}^{-1}\right), \mathrm{e}_{0}$ is the water vapor pressure computed by water surface temperature (hPa), and $\mathrm{e}_{2}$ is the water vapor pressure at $2.0 \mathrm{~m}$ above the ground surface $(\mathrm{hPa})$.

Magnus [44] created the first version for estimating saturated vapor pressure by the empiric method. Several scientists developed the Magnus formula. The equation by Matveev [45] was used for this research (Equation (14)).

$$
\mathrm{e}=6.108 \cdot 10^{(\mathrm{at}) \cdot(\mathrm{b}+\mathrm{t})^{-1}}
$$

where if $\mathrm{t}<0^{\circ} \mathrm{C}$, then $\mathrm{a}=9.5, \mathrm{~b}=265.5$; if $\mathrm{t}>0{ }^{\circ} \mathrm{C}$, then $\mathrm{a}=7.63, \mathrm{~b}=241.9$, and $\mathrm{t}$ is temperature.

It lacks long-term measurement of lake surface temperature in Mongolia. Thus, to calculate the saturated vapor pressure at the surface, lake mix-layer temperature and lake ice temperature have been taken from the Fifth Generation of European Centre for Medium-Range Weather Forecasts (ECMWF) atmospheric reanalysis of the global climate (ERA5) [46] for estimating evaporation from the water surface area of the Ugii Nuur Lake.

The measured height of wind is $10 \mathrm{~m}$ above ground at each meteorological observation site [47]. The version of the empirical equation suggested by the WMO based on the law by Hellman [48] was used for estimating wind speed at $2 \mathrm{~m}$ above the ground surface (Equation (15)) [49].

$$
\mathrm{v}_{\mathrm{h}}=\mathrm{v}_{10}[0.233+0.656 \lg (\mathrm{h}+4.75)]
$$

where $v_{h}$ is the estimated wind speed at a given $h$ level and $v_{10}$ is the measured wind speed at $10 \mathrm{~m}$ level.

\section{Results and Discussion}

\subsection{Changes in Lake Water Surface Area}

The water surface area of the Ugii Nuur Lake was estimated by using ArcGIS software with Landsat satellite data. Then, data were analyzed in the time series. Table 1 shows the water surface area of the lake in each August between 1986 and 2018.

Figure 3 illustrates the inter-annual variation of the water surface area of the Ugii Nuur Lake. The area of the lake decreased if we compared the water surface area in 1986 and 2018. However, among these years, water surface areas of the Ugii Nuur Lake have been showing several increases and decreases. For instance, the water surface area of the lake decreased from 1986 to the 1990s, but it gradually increased until the 2000s. The area of the lake was rapidly decreasing until 2011, and then it grew until 2018. 
Table 1. Water surface area of the Ugii Nuur Lake, $\mathrm{km}^{2}$.

\begin{tabular}{cccccccccccc}
\hline Years & 1986 & 1987 & 1988 & 1989 & 1990 & 1991 & 1992 & 1993 & 1994 & 1995 & 1996 \\
Lake area & 26.04 & 25.96 & 25.84 & 24.45 & 25.98 & 26.74 & 25.74 & 26.43 & 26.48 & 26.78 & 25.88 \\
\hline Years & 1997 & 1998 & 1999 & 2000 & 2001 & 2002 & 2003 & 2004 & 2005 & 2006 & 2007 \\
Lake area & 25.91 & 26.17 & 25.89 & 27.11 & 25.69 & 24.81 & 24.95 & 25.30 & 25.43 & 24.80 & 24.35 \\
\hline Years & 2008 & 2009 & 2010 & 2011 & 2012 & 2013 & 2014 & 2015 & 2016 & 2017 & 2018 \\
Lake area & 23.68 & 22.79 & 22.24 & 21.80 & 22.16 & 22.52 & 23.37 & 23.13 & 24.19 & 24.38 & 24.60 \\
\hline
\end{tabular}

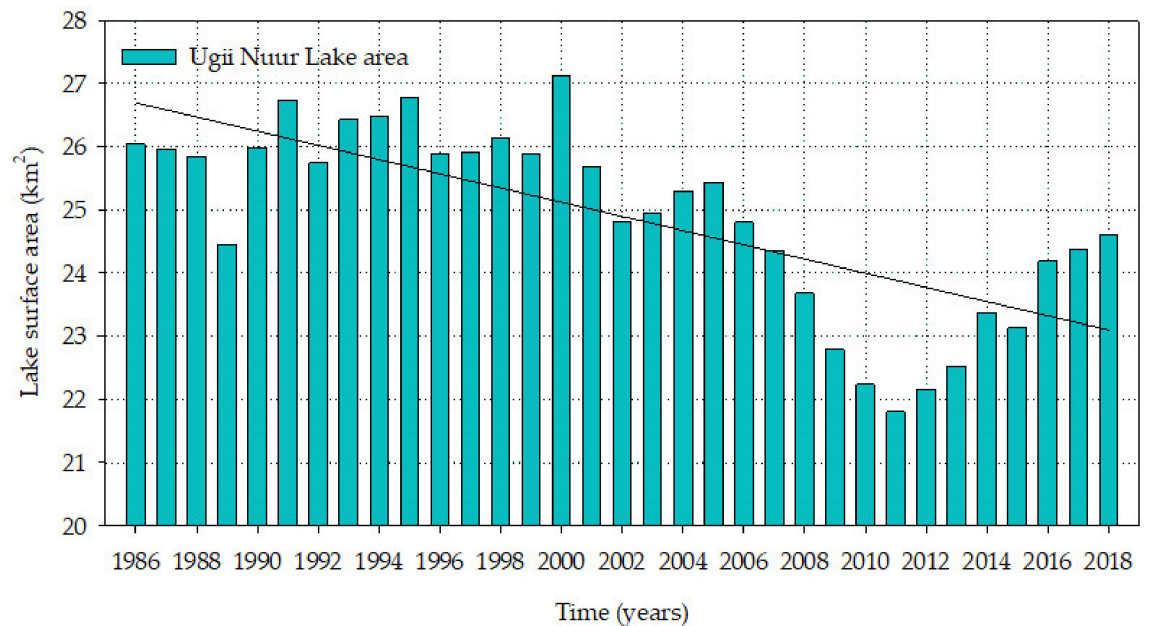

Figure 3. Variation trend of the water surface area of the Ugii Nuur Lake.

Figure 4 shows the water surface area of the lake and its spatial change in August 1986 and 2018 by satellite image. According to the changes in the lake surface area, the largest lake area was observed in 2000 with an area of $27.11 \mathrm{~km}^{2}$, while the smallest area was $21.80 \mathrm{~km}^{2}$ in 2011 . The average water surface area of the Ugii Nuur Lake is about $24.90 \mathrm{~km}^{2}$. In 1986, the lake area was $26.04 \mathrm{~km}^{2}$ and then it decreased to $24.40 \mathrm{~km}^{2}$ in 2018. Long-term observations of the water surface area of the lake revealed that the lake area has decreased by $13.5 \%$ within the last 33 years (Figure 5).

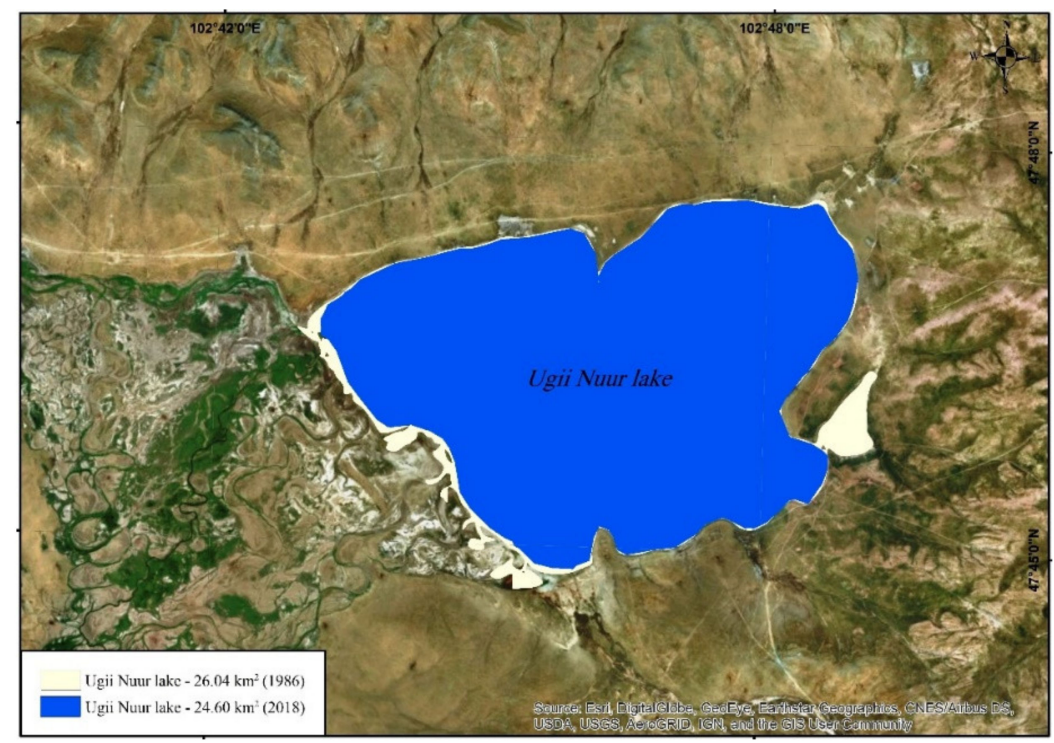

Figure 4. Spatiotemporal changes in the water surface area of the Ugii Nuur Lake from 1986 to 2018.

For showing a decline in time series of the water surface areas of the Ugii Nuur Lake calculated by the NDWI index from Landsat satellite, the imagery of the lake for every four years from 1986 to 
2018 is shown in Figure 5. The shape and surface area of the lake have considerably changed over the last 30 years.

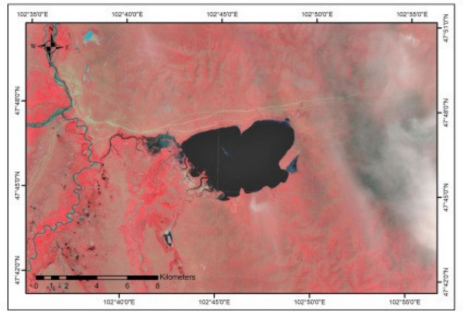

1986

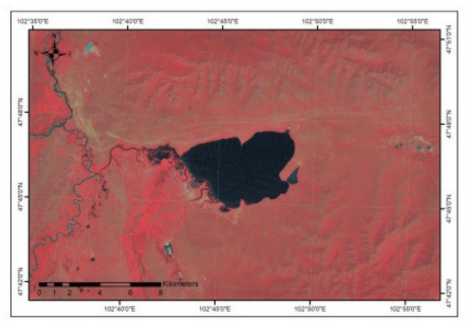

1998

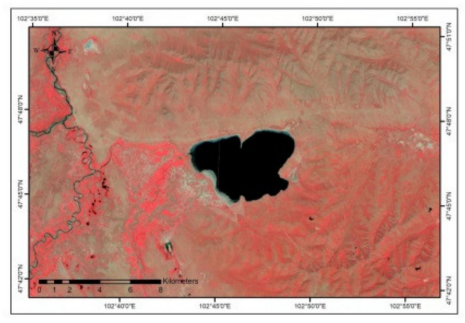

2010

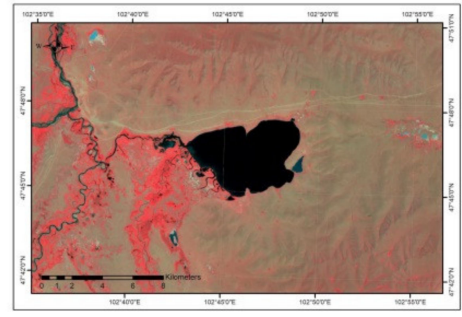

1990

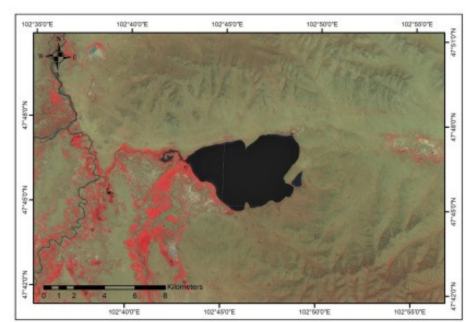

2002

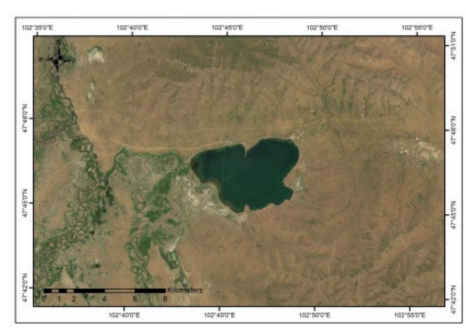

2014

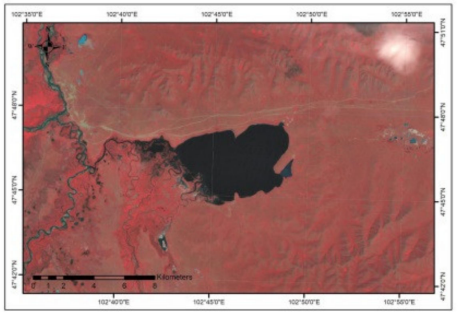

1994

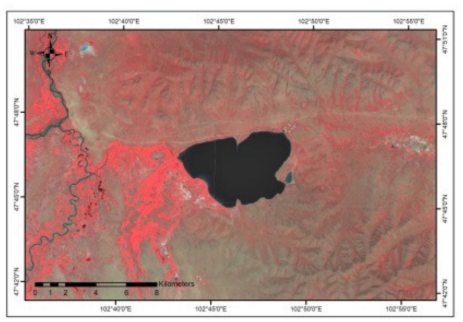

2006

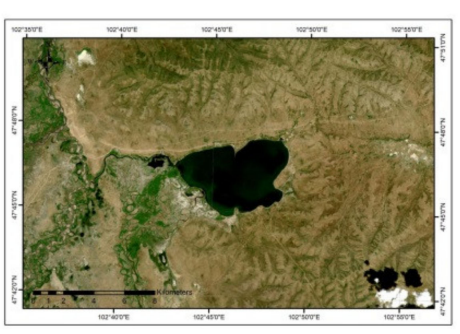

2018

Figure 5. The Ugii Nuur Lake in different selected years.

The water resources and morphometric parameters of the lake were obtained by satellite remote sensing data [50]. The water level data measured at the Ugii Nuur Lake from 2002 to 2018 were compared with the water surface area of the lake obtained from remote sensing data (Figure 6).
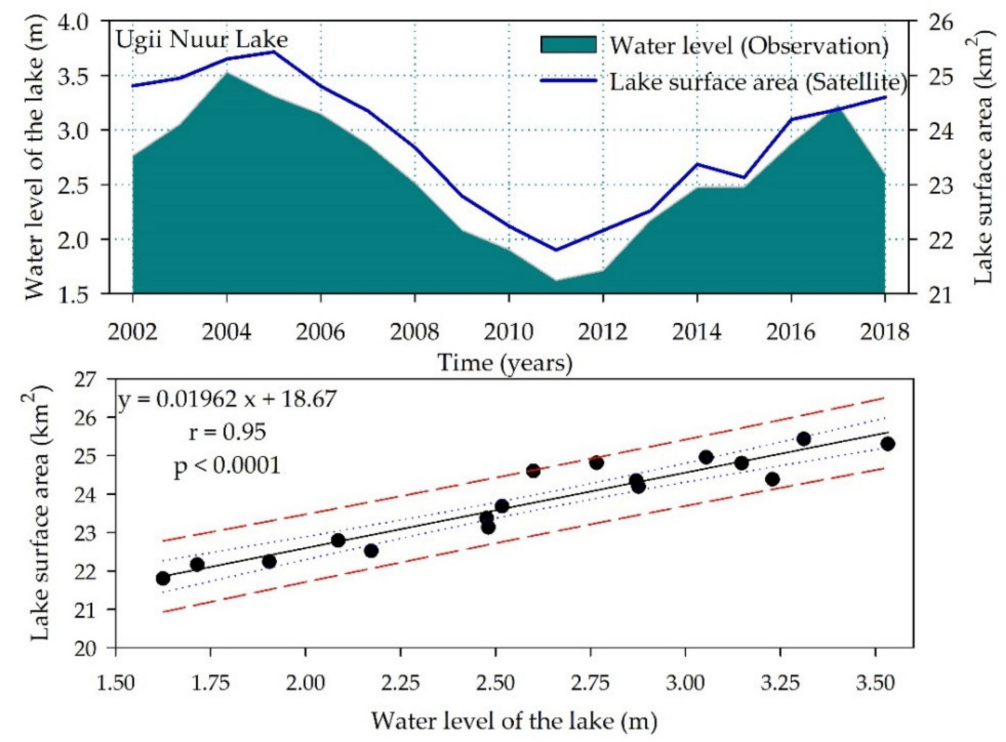

Figure 6. Linear regression for a relationship between water level and surface area of the Ugii Nuur Lake. 
Figure 6 shows that the variation of lake water surface area has a strong positive correlation with the change of lake water level $(r=0.95)$. A strong relationship between those lake morphometric parameters matches with the study results of Shang [51] and Fang [52]. Thus, data for the water surface area of the lake estimated by the NDWI products from Landsat satellite can be used for further studies.

\subsection{Trend Analysis}

The trend analysis was carried out by using MK, ITAM, and Sen's estimator Test methods with the data series of climate and hydrological measurements at the Ugii Nuur Lake Basin from 1986 to 2018.

\subsubsection{Air Temperature Analysis}

The annual average air temperature for the Ugii Nuur weather station was $1.2^{\circ} \mathrm{C}$ between 1986 and 2018. It was a maximum of $3.3^{\circ} \mathrm{C}$ in 2017 and a minimum of $-1.2^{\circ} \mathrm{C}$ in 1986 . Analysis of annual average air temperature (change of parameter) by the MK trend method shows a sharp increase at the Ugii Nuur Weather Station. Such a sharp statistical increase started in 1986 and has been observed in 2008 and $2018(Z=4.595)$. The rise in annual average air temperature was also confirmed by the results provided by Innovative Trend $(\varphi=16.076)$ and Sen's Slope Estimator Test $(\beta=0.065)$ methods (Figure 7).

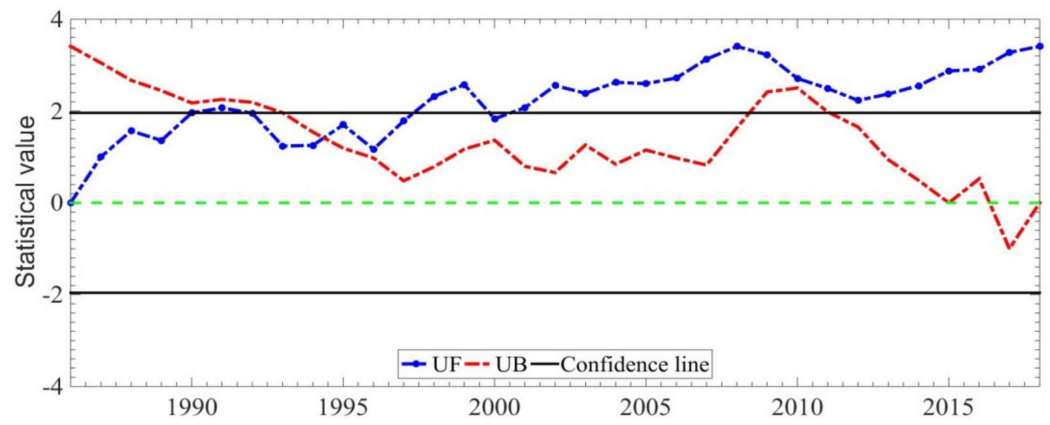

Figure 7. The trend of annual average air temperature at the Ugii Nuur Lake site (where UF and UB are parameters of the change, $\mathrm{UB}=-\mathrm{UF}$ ).

\subsubsection{Precipitation Analysis}

The total annual precipitation at the Ugii Nuur weather station was $256.6 \mathrm{~mm}$ as the average between 1986 and 2018. It was a maximum of $380.5 \mathrm{~mm}$ in 1994 and a minimum of $170.8 \mathrm{~mm}$ in 2002. Analysis of total annual precipitation series shows a slight decline from 1994 to 2010s. Then, the annual precipitation exhibited an increasing trend from 2010 to 2018. A significantly statistical decline was observed in $2010(Z=-0.902)$ at the Ugii Nuur Weather Station based on the Mann-Kendall analysis approach. The change of trends was consistent with the other two methods, Innovative Trend $(\varphi=-0.542)$ and Sen's Slope Estimator Test $(\beta=-0.888)$ (Figure 8).

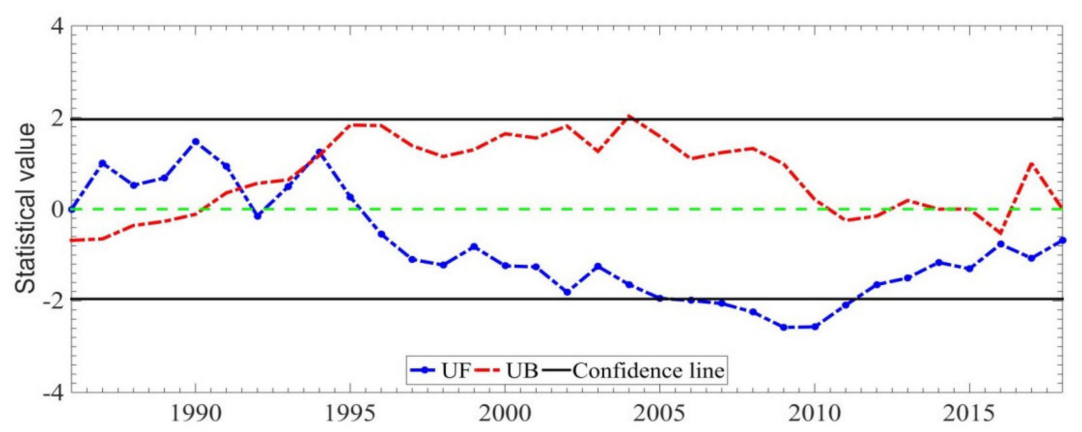

Figure 8. The trend of total annual precipitation at the Ugii Nuur Lake site (where UF and UB are parameters of the change, $\mathrm{UB}=-\mathrm{UF})$. 


\subsubsection{River Discharge Analysis}

The total annual inflow river discharge at the Khogshin Orkhon river gauge station was $36.2 \mathrm{~mm}$ as the average between 1986 and 2018. It was a maximum of $147.3 \mathrm{~mm}$ in 1994 and a minimum of 0.6 in 2010. Analysis of the total annual discharge series of the Khogshin Orkhon River shows a reversely rapid decrease of river discharge from 1988 to 2018. A statistically rapid drop in river discharge was observed from 2005 to 2018 ( $Z=-5.392)$ based on the Mann-Kendall analysis approach. The change of trends also was consistent with the other two methods by Innovative Trend ( $\varphi=-6.511)$ and Sen's Slope Estimator Test $(\beta=-0.015)$ (Figure 9).

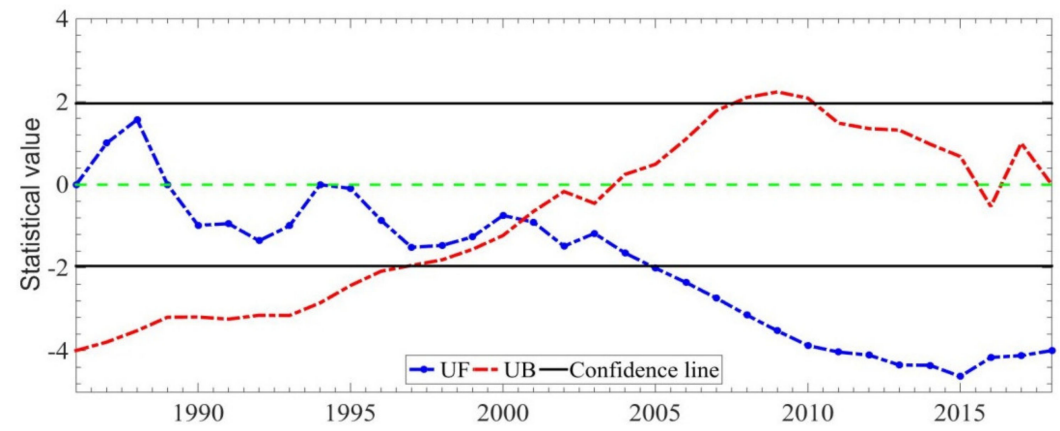

Figure 9. The trend of the total annual discharge of the Khogshin Orkhon River, which is an inflow of the Ugii Nuur Lake (where UF and UB are parameters of the change, UB $=-U F$ ).

\subsubsection{Evaporation Analysis}

The total annual evaporation from the Ugii Nuur Lake was $110.5 \mathrm{~mm}$ as the average between 1986 and 2018. It was a maximum of $222.2 \mathrm{~mm}$ in 2017 and a minimum of $50.8 \mathrm{~mm}$ in 1990. Analysis of total annual evaporation (parameter change) by the Mann-Kendall trend method shows a sharp increase at the Ugii Nuur Lake. A statistically sharp increase started in the 1990s and has also been observed from 2013 to 2018 ( $\mathrm{Z}=4.385$ ). This increase in total annual evaporation also was confirmed by the results provided by Innovative Trend $(\varphi=4.328)$ and Sen's Slope Estimator Test $(\beta=2.256)$ methods (Figure 10).

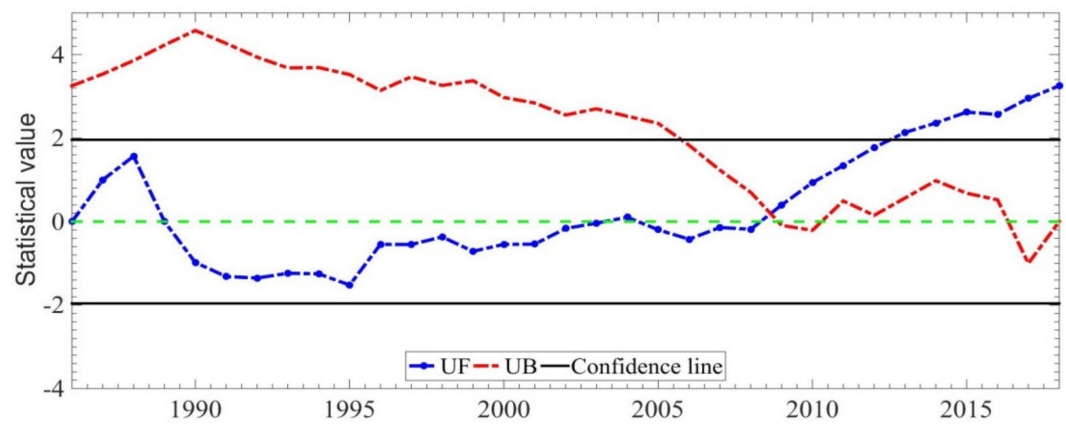

Figure 10. The trend of total annual evaporation at the Ugii Nuur Lake (where UF and UB are parameters of the change, UB $=-\mathrm{UF})$.

\subsubsection{Analysis of the Water Surface Area of the Lake}

The water surface area has a decreasing trend $(Z=-6.021)$ from 1986 to 2018 by the Mann-Kendall trend method. During the period from 1986 to 2000, the lake water surface area showed a gradually increasing trend. From 2000 to 2018, the water surface area of the lake had a statistically sharp decreasing trend according to the Mann-Kendall trend analysis. The above results on the lake water surface area by the Mann-Kendall method were the same as the outputs by Innovative Trend $(\varphi=-0.896)$ and Sen's Slope Estimator Test $(\beta=-0.102)$ (Figure 11). 


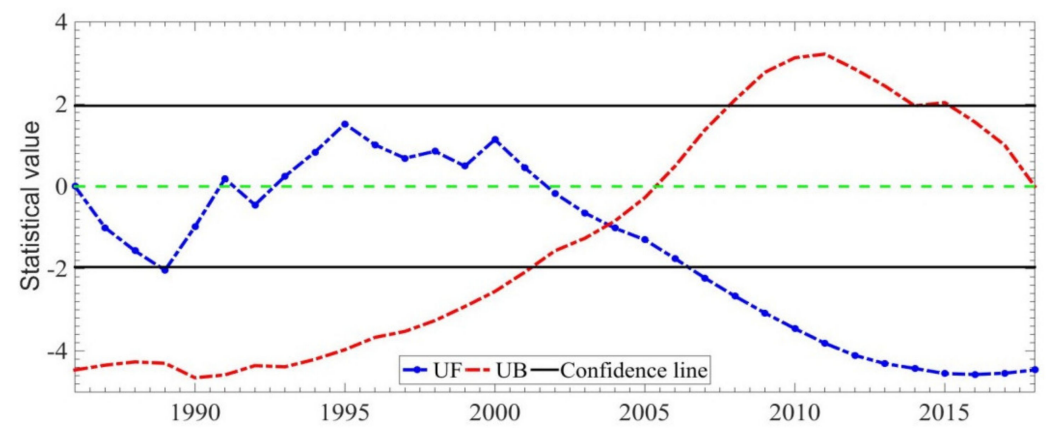

Figure 11. The trend of the annual mean lake area of the Ugii Nuur Lake (where UF and UB are parameters of the change, $\mathrm{UB}=-\mathrm{UF})$.

MK, ITAM, and Sen's Slope Estimator approaches have been used for trend analysis of several parameters, such as long-term average annual air temperature, total annual precipitation, total annual inflow river discharge, total annual evaporation at the Ugii Nuur Lake Basin, and the water surface area of the Ugii Nuur Lake (Table 2).

Table 2. Comparison of results by Mann-Kendal (MK), Innovative Trend (ITAM), and Sen's Slope Estimator Test.

\begin{tabular}{ccccc}
\hline No & Parameters & $\begin{array}{c}\text { Mann-Kendall } \\
\text { Trend Analysis }\end{array}$ & $\begin{array}{c}\text { Innovative } \\
\text { Trend Analysis }\end{array}$ & $\begin{array}{c}\text { Sen's } \\
\text { SlopeEstimator } \\
\text { Test Approach }\end{array}$ \\
\hline 1 & $\begin{array}{c}\text { Trend of annual average air } \\
\text { temperature }\end{array}$ & $4.595^{* * *}$ & $16.076^{* * *}$ & 0.065 \\
2 & Trend of total annual precipitation & -0.902 & -0.542 & -0.888 \\
3 & Trend of total annual river discharge & $-5.392^{* * *}$ & $-6.511^{* * *}$ & -0.015 \\
4 & Trend of total annual evaporation & $4.385^{* * *}$ & $4.328^{* * *}$ & $2.256^{* *}$ \\
5 & Trend of water surface area & $-6.021^{* * *}$ & -0.896 & -0.102 \\
\hline
\end{tabular}

${ }^{*} 0.1$ trend with low variation; ${ }^{* *} 0.05$ trend with relative changes; ${ }^{* * *} 0.01$ trend with high variation.

Table 2 presents the annual trend analysis of hydro-meteorological variables and the water surface area of the lake in the station by the MK test, ITAM, Sen's slope estimator test. Hence, the increase and decrease in innovative trend analysis $\varphi$ test value predicted that the magnitude becomes strong.

\subsection{Impact of Cimate Parameters and Water Balance Components on the Water Surface Area of the Ugii Nuur Lake}

According to the results of Mann-Kendall, Innovative Trend, and Estimator test methods for time series of climate and hydrological variables shown in Section 3.2, a decrease was observed in water surface area of the lake with the satellite data, showing a negative correlation with a sharp increase in annual average air temperature and total annual evaporation, while a positive correlation with a decrease in total annual river discharge and total annual precipitation was also observed. According to the results of MK, ITAM, and Sen's Estimator test methods for the time series of climate and hydrological variables shown in Section 3.2, a decrease was observed in the water surface area of the lake estimated from the satellite data. Moreover, annual average air temperature and total annual evaporation showed a sharp increase, while total annual river discharge and total annual precipitation showed a decrease. The results were consistent with the studies conducted by Chebud and Melesse [53].

Statistical analysis has been done between different components of the lake water balance and climatic factors [54] by using hydro-meteorological data measured at the Ugii Nuur Lake Basin and water surface area of the lake obtained from Landsat satellite from 1986 to 2018. Figure 12 illustrated the results in the analysis mentioned above. 


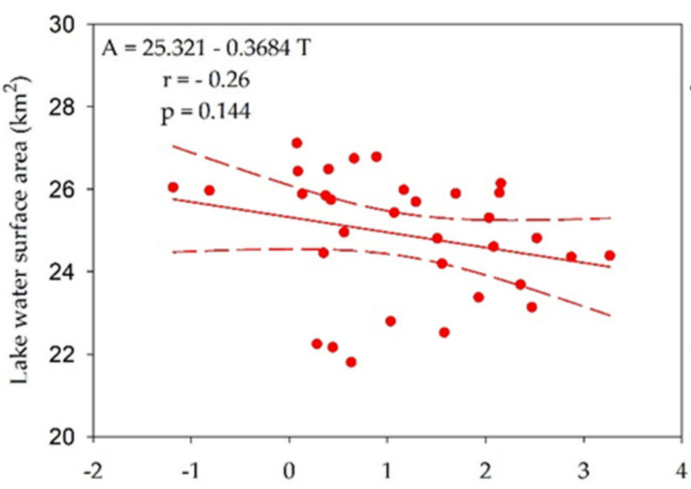

(a) Annual average air temperature $\left({ }^{\circ} \mathrm{C}\right)$

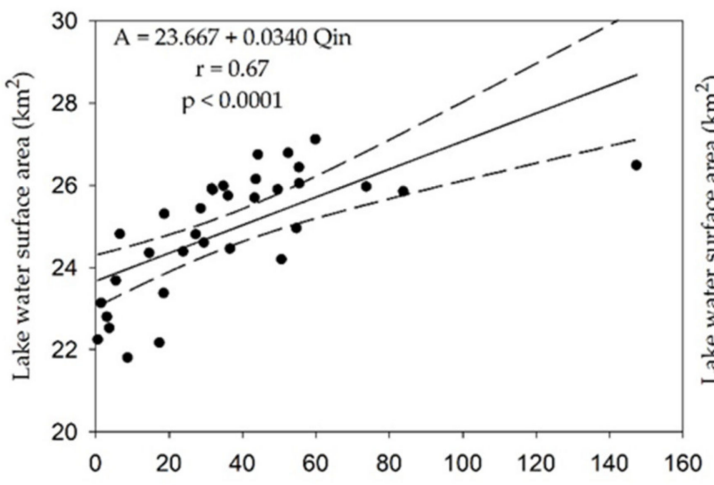

(c) Total annual inflow river discharge $(\mathrm{mm})$

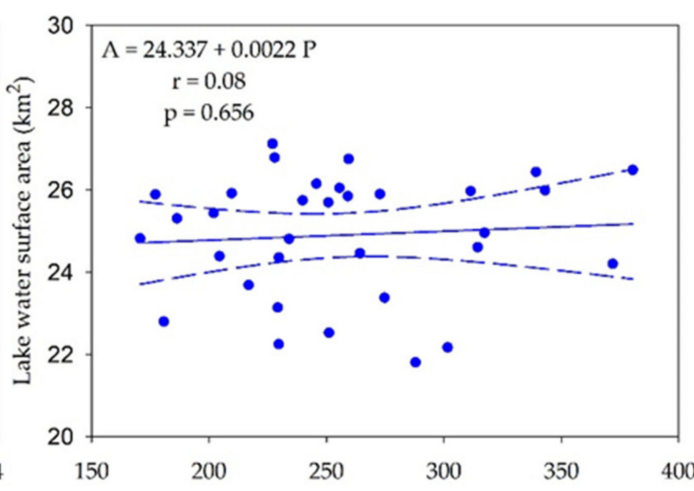

(b) Total annual precipitation ( $\mathrm{mm}$ )

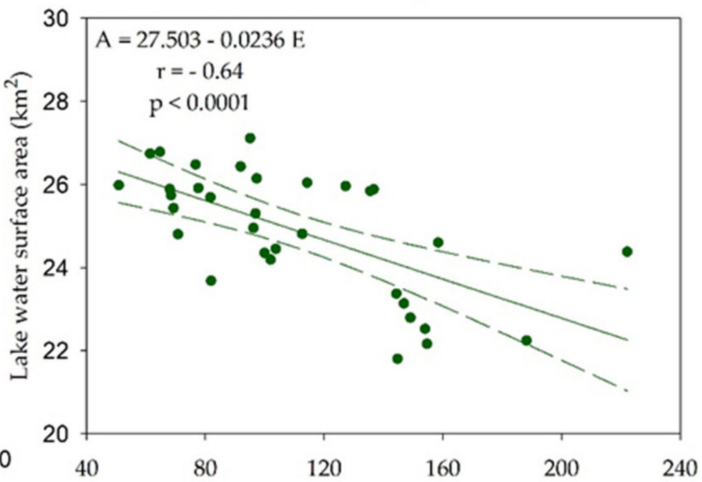

(d) Total annual evaporation ( $\mathrm{mm}$ )

Figure 12. Linear regression for a relationship between the water surface area of the lake and variables such as (a) air temperature, (b) precipitation, (c) river flow, and (d) evaporation.

The scatter chart in Figure 12 showed that the water surface area of the Ugii Nuur Lake had a reverse correlation with annual average air temperature and total annual evaporation. In contrast, it had a direct correlation with the total annual river discharge or inflow and total annual precipitation [22,52]. The correlation coefficients between the annual average air temperature and lake surface area were -0.26 . In other words, the increase of annual average air temperature led to an increase of total annual evaporation, and this caused a decrease in the water surface area of the lake. Thus, the effect of the regime of annual average air temperature on the lake surface was weak (Figure 12a).

The surface area of the lake is directly dependent on the volume of the lake [51]. Therefore, it is necessary to investigate the relationship between lake surface area and components of the water balance, such as total annual precipitation, river discharge, and evaporation. The correlation coefficient between the total annual precipitation and lake surface area was 0.08 (Figure $12 \mathrm{~b}$ ). If the precipitation amount increases, the lake surface area will expand. However, total annual precipitation has decreased by $7.1 \%$ for the 33 years of the period from 1986 to 2018. The decrease rate in precipitation was about two times less than the decrease in the lake surface area mentioned in Section 3.1. In other words, small decreases in total annual precipitation led to a weak correlation with the lake surface area. The weak relationship was confirmed by the result of a slight decrease $(Z=-0.902)$ calculated using the MK analysis in Section 3.2.2. The correlation coefficient between total annual river discharge and the lake water surface area was 0.67 , which indicates that it had a positive and moderate effect on the water surface area of the lake (Figure 12c). A decrease in the total annual inflow river discharge brought a decline in the lake water surface area. It was confirmed by the result of a statistically significant decrease $(\mathrm{Z}=-5.392)$ calculated by the MK analysis in 3.2.3. The correlation coefficient between total annual evaporation and lake water surface area was -0.64 or a negative and moderate (Figure 12d). That is to say, if the total annual evaporation rate grows, the lake surface area will decrease. The moderate 
relationship was confirmed by the result of a statistically sharp increase $(Z=4.385)$ calculated by the MK analysis in Section 3.2.4.

From the above results, the average annual air temperature and the total annual precipitation were not strongly related to the surface area of the lake. However, the total annual river flow and the total annual evaporation had a strong relationship with the surface area of the lake. In other words, the total annual evaporation and inflow river discharge were the essential hydro-meteorological factors affecting the surface area of the Ugii Nuur Lake. Therefore, the multiple regression equation of the lake surface area depending on the total annual evaporation and the total annual river discharge was obtained (Equation (17)).

$$
\mathrm{A}=25.82396+0.025622 \mathrm{Q}-0.01679 \mathrm{E}
$$

where, $\mathrm{A}$ is the lake water surface area $\left(\mathrm{km}^{2}\right), \mathrm{Q}$ is total annual river discharge $(\mathrm{mm})$, and is total annual evaporation $(\mathrm{mm})$.

Determination coefficient and statistical significance in equation 17 was $\mathrm{r}^{2}=0.64$ and $\mathrm{p}<0.0001$, respectively. It means that $64 \%$ of the variations in the water surface area of the Ugii Nuur Lake related to the variability of the total annual evaporation and the total annual river discharge by the equation. The remaining $36 \%$ can be explained by other factors that were not chosen for the regression model. The surface area of the lake was found using Equation (17) and then compared with the values calculated from the satellite imagery (Figure 13).

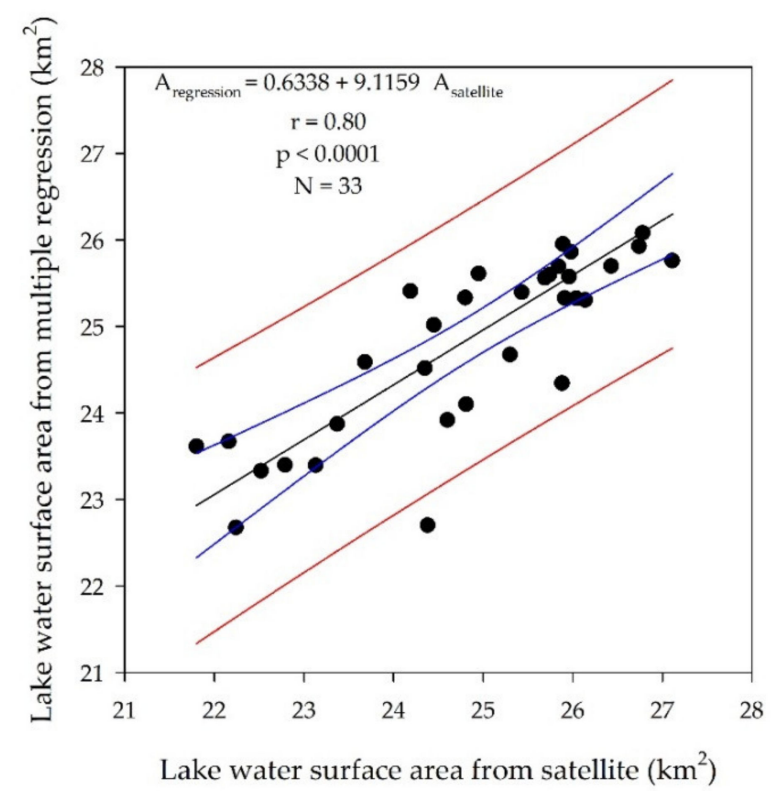

Figure 13. A relationship between lake surface areas estimated from satellite and multiple regression equation.

The correlation coefficient between satellite and model values of the lake water surface area was $\mathrm{r}=0.80(\mathrm{p}<0.0001)$, and they had a positive and strong relationship with each other. It validated the results of Figure 12.

The results of several studies showed that recent global climate change influenced the surface area of the lake [21,55-59]. It indicated that a decrease in the total annual inflow river discharge and an increase in total annual evaporation were crucial hydro-meteorological factors on the reduction of the water surface area of the Ugii Nuur Lake. The study was a baseline study of lakes in Mongolia's steppe region as a benchmark for determining how much of the lake area is affected by recent global climate change. It was consistent with the results of Tao et al.'s [8] study on Mongolian plateau lakes. 
The Ugii Nuur Lake surface area has sharply decreased since 1995 (Figure 11) [25,60]. It may be related to the impact of groundwater and also the socio-economic activities, including fishing, agriculture, and tourism in the lake basin.

\section{Conclusions}

In this study, Landsat satellite NDWI multi-channel data were used to calculate the values of the Ugii Nuur Lake surface area from 1986 to 2018. The satellite data was validated by the measurement of the lake water level $(r=0.95)$. The lake surface area has decreased by $13.5 \%$ for the period from 1986 to 2018 .

Non-parametric trend analysis in hydro-climatic variables was used to determine the reasons for changes in the lake water surface area. The Mann-Kendall trend analysis has indicated a slight decrease in total annual precipitation $(Z=-0.902)$ and inflow river discharge $(Z=-5.392)$, respectively. In contrast, a statistically significant increase was seen in a trend in total annual evaporation $(Z=4.385)$ and annual average air temperature $(Z=4.595)$. The total impact of the changes in the above variables has led to a dramatic change in the water surface area of the Ugii Nuur Lake. All the results were confirmed by ITAM and the Sen's Slope Estimator Test Approach. All results were confirmed by ITAM and the Sen's Slope Estimator Test Approach.

Correlation and regression analysis of several hydro-meteorological variables representing global climate change were related to the lake surface area. The analysis showed that the most critical factors affecting the water surface area of the Ugii Nuur Lake were the total annual evaporation $(r=-0.64)$ and the total annual inflow river discharge $(r=0.67)$.

In the near future, it is vital to conduct scientific studies considering the volume of lake water, groundwater, and the anthropogenic impact.

Author Contributions: Conceptualization, E.S., S.D., and A.E.; methodology, B.D., and M.G.; software, T.G., and K.W.; validation, D.Y., H.W., and B.W.; formal analysis, B.D.; investigation, S.D.; resources, O.D.; writing-original draft preparation, E.S., and A.E.; writing-review and editing, O.D., A.A., A.G., and W.B.; visualization, Y.Y. and B.G.; supervision, T.Q., and D.Y.; project administration, D.Y.; funding acquisition, H.W., D.Y., and A.E. All authors have read and agreed to the published version of the manuscript.

Funding: This study was funded by the National Key Research and Development Project of China (grant 2016YFA0601503). Moreover, financial support for this study was provided by the Young Scientist Grant (P2018-3568) at the National University of Mongolia.

Acknowledgments: The authors would like to thank the Information and Research Institute of Meteorology, Hydrology, and Environment of Mongolian for providing the raw hydro-meteorological data. We also thank the China Institute of Water Resources and Hydropower Research for financing this research.

Conflicts of Interest: The authors declare no conflict of interest.

\section{References}

1. Dorjsuren, B.; Yan, D.; Wang, H.; Chonokhuu, S.; Enkhbold, A.; Davaasuren, D.; Girma, A.; Abiyu, A.; Jing, L.; Gedefaw, M. Observed trends of climate and land cover changes in Lake Baikal basin. Environ. Earth Sci. 2018, 77, 725. [CrossRef]

2. Lioubimtseva, E.; Cole, R.; Adams, J.M.; Kapustin, G. Impacts of climate and land-cover changes in arid lands of Central Asia. J. Arid Environ. 2005, 62, 285-308. [CrossRef]

3. Lioubimtseva, E.; Simon, B.; Faure, H.; Faure-Denard, L.; Adams, J.M. Impacts of climatic change on carbon storage in the Sahara-Gobi desert belt since the Last Glacial Maximum. Global Planetary Change 1998, 16-17, 95-105. [CrossRef]

4. Malsy, M.; Aus der Beek, T.; Eisner, S.; Flörke, M. Climate change impacts on Central Asian water resources. Adv. Geosci. 2012, 32, 77-83. [CrossRef]

5. Lioubimtseva, E.; Henebry, G.M. Climate and environmental change in arid Central Asia: Impacts, vulnerability, and adaptations. J. Arid Environ. 2009, 73, 963-977. [CrossRef]

6. Nandintsetseg, B.; Greene, J.S.; Goulden, C.E. Trends in extreme daily precipitation and temperature near lake Hövsgöl, Mongolia. Internat. J. Climatol. 2007, 27, 341-347. [CrossRef] 
7. Liancourt, P.; Boldgiv, B.; Song, D.S.; Spence, L.A.; Helliker, B.R.; Petraitis, P.S.; Casper, B.B. Leaf-trait plasticity and species vulnerability to climate change in a Mongolian steppe. Glob. Change Biol. 2015, 21, 3489-3498. [CrossRef]

8. Tao, S.; Fang, J.; Zhao, X.; Zhao, S.; Shen, H.; Hu, H.; Tang, Z.; Wang, Z.; Guo, Q. Rapid loss of lakes on the Mongolian Plateau. Proc. Natl. Acad. Sci. USA 2015, 112, 2281-2286. [CrossRef]

9. Wang, W.; Ma, Y.; Feng, Z.; Narantsetseg, T.; Liu, K.-B.; Zhai, X. A prolonged dry mid-Holocene climate revealed by pollen and diatom records from Lake Ugii Nuur in central Mongolia. Quat. Int. 2011, 229, 74-83. [CrossRef]

10. Walther, M.; Gegeensuvd, T. Ugii Nuur (Central Mongolia) Paleo Environmental Studies of Lake Level Fluctuations and Holocene Climate Change. Geographica-Oekologica 2005, 2, 36.

11. Jimee, T. A catalog of lakes in Mongolia; Shuvuun Saaral Publishing: Ulaanbaatar, Mongolia, 2000; pp. $15-16$.

12. Schwanghart, W.; Schütt, B.; Walther, M. Holocene climate evolution of the Ugii Nuur basin, Mongolia. Adv. Atmos. Sci. 2008, 25, 986-998. [CrossRef]

13. Schwanghart, W.; Schütt, B. Holocene morphodynamics in the Ugii Nuur basin, Mongolia-insights from a sediment profile and 1D electrical resistivity tomography. Zeitschrift für Geomorphologie, Supplementary Issues 2008, 52, 35-55. [CrossRef]

14. Tsegmid, S. Physical geography of Mongolia; Institute of Geography and Permafrost, Mongolia, Mongolian Academy of Sciences, Press of State Publishing: Ulaanbaatar, Mongolia, 1969; pp. 148-153.

15. Fukumoto, Y.; Kaoru, K.; Orkhonselenge, A.; Ganzorig, U. Holocene environmental changes in northern Mongolia inferred from diatom and pollen records of peat sediment. Quat. Int. 2012, 254, 83-91. [CrossRef]

16. Wang, W.; Ma, Y.; Feng, Z.; Meng, H.; Sang, Y.; Zhai, X. Vegetation and climate changes during the last 8660 cal. a BP in central Mongolia, based on a high-resolution pollen record from Lake Ugii Nuur. Chin. Sci. Bul. 2009, 54, 1579-1589. [CrossRef]

17. Pagma, K.; Peck, J.A.; Fowell, S.J. Lake Systems and Paleoclimate investigation of the Holocene, Mongolia. In Proceedings of the Mongolian Academy of Sciences; Mongolian Academy of Sciences: Ulaanbaatar, Mongolia, 2002; Volume 42, pp. 67-89.

18. Information and Research Institute of Meteorology Hydrology and Environment of Mongolia. Assessment of Water Resources of Lakes in Mongolia Based on Land and Satellite Data Information; Project report. Press of Admon printing: Mongolia, Ulaanbaatar, 2018; pp. 123-124.

19. Bai, J.; Chen, X.; Li, J.; Yang, L.; Fang, H. Changes in the area of inland lakes in arid regions of central Asia during the past 30 years. Environ. Monit. Assess. 2011, 178, 247-256. [CrossRef]

20. Huang, J.; Ji, M.; Xie, Y.; Wang, S.; He, Y.; Ran, J. Global semi-arid climate change over last 60 years. Clim. Dyn. 2016, 46, 1131-1150. [CrossRef]

21. Valeyev, A.; Karatayev, M.; Abitbayeva, A.; Uxukbayeva, S.; Bektursynova, A.; Sharapkhanova, Z. Monitoring Coastline Dynamics of Alakol Lake in Kazakhstan Using Remote Sensing Data. Geosciences 2019, 9, 404. [CrossRef]

22. Li, X.-Y.; Xu, H.-Y.; Sun, Y.-L.; Zhang, D.-S.; Yang, Z.-P. Lake-Level Change and Water Balance Analysis at Lake Qinghai, West China during Recent Decades. Water Resour. Manag. 2007, 21, 1505-1516. [CrossRef]

23. Yin, X.; Nicholson, S.E. The water balance of Lake Victoria. Hydrol. Sci. J. 1998, 43, 789-811. [CrossRef]

24. Tamaddun, K.A.; Kalra, A.; Bernardez, M.; Ahmad, S. Effects of ENSO on Temperature, Precipitation, and Potential Evapotranspiration of North India's Monsoon: An Analysis of Trend and Entropy. Water 2019, 11, 189. [CrossRef]

25. Dorjsuren, B.; Yan, D.; Wang, H.; Chonokhuu, S.; Enkhbold, A.; Yiran, X.; Girma, A.; Gedefaw, M.; Abiyu, A. Observed Trends of Climate and River Discharge in Mongolia's Selenga Sub-Basin of the Lake Baikal Basin. Water 2018, 10, 1436. [CrossRef]

26. Archive and Database center at the National Agency of Meteorology and Environment of Mongolia. Available online: http://namem.gov.mn/ (accessed on 15 September 2019).

27. USGS Global Visualization Viewer. Available online: https://glovis.usgs.gov (accessed on 1 March 2013).

28. McFeeters, S.K. The use of the Normalized Difference Water Index (NDWI) in the delineation of open water features. Int. J. Remote Sens. 1996, 17, 1425-1432. [CrossRef]

29. Ma, M.; Wang, X.; Veroustraete, F.; Dong, L. Change in area of Ebinur Lake during the 1998-2005 period. Int. J. Remote Sens. 2007, 28, 5523-5533. [CrossRef] 
30. Lu, S.; Ouyang, N.; Wu, B.; Wei, Y.; Tesemma, Z. Lake water volume calculation with time series remote-sensing images. Int. J. Remote Sens. 2013, 34, 7962-7973. [CrossRef]

31. Mao, D.; Wang, Z.; Yang, H.; Li, H.; Thompson, J.R.; Li, L.; Song, K.; Chen, B.; Gao, H.; Wu, J. Impacts of Climate Change on Tibetan Lakes: Patterns and Processes. Remote Sens. 2018, 10, 358. [CrossRef]

32. Gedefaw, M.; Wang, H.; Yan, D.; Song, X.; Yan, D.; Dong, G.; Wang, J.; Girma, A.; Ali, B.; Batsuren, D.; et al. Trend Analysis of Climatic and Hydrological Variables in the Awash River Basin, Ethiopia. Water 2018, 10, 1554. [CrossRef]

33. Gedefaw, M.; Yan, D.; Wang, H.; Qin, T.; Wang, K. Analysis of the Recent Trends of Two Climate Parameters over Two Eco-Regions of Ethiopia. Water 2019, 11, 161. [CrossRef]

34. Li, Y.; Sheng, Z.; Jing, J. Feature analysis of stratospheric wind and temperature fields over the Antigua site by rocket data. Earth Planet. Phys. 2019, 3, 414-424. [CrossRef]

35. Livada, I.; Synnefa, A.; Haddad, S.; Paolini, R.; Garshasbi, S.; Ulpiani, G.; Fiorito, F.; Vassilakopoulou, K.; Osmond, P.; Santamouris, M. Time series analysis of ambient air-temperature during the period 1970-2016 over Sydney, Australia. Sci. Total Environ. 2019, 648, 1627-1638. [CrossRef]

36. Gedefaw, M.; Yan, D.; Wang, H.; Qin, T.; Girma, A.; Abiyu, A.; Batsuren, D. Innovative Trend Analysis of Annual and Seasonal Rainfall Variability in Amhara Regional State, Ethiopia. Atmosphere 2018, 9, 326. [CrossRef]

37. Cherinet, A.A.; Yan, D.; Wang, H.; Song, X.; Qin, T.; Kassa, M.T.; Girma, A.; Dorjsuren, B.; Gedefaw, M.; Wang, H.; et al. Impacts of Recent Climate Trends and Human Activity on the Land Cover Change of the Abbay River Basin in Ethiopia. Adv. Meteorol. 2019, 2019, 14. [CrossRef]

38. Zhao, L.; Xia, J.; Xu, C.-y.; Wang, Z.; Sobkowiak, L.; Long, C. Evapotranspiration estimation methods in hydrological models. J. Geogr. Sci. 2013, 23, 359-369. [CrossRef]

39. Mbanguka, R.P.; Lyon, S.W.; Holmgren, K.; Girons Lopez, M.; Jarsjö, J. Water Balance and Level Change of Lake Babati, Tanzania: Sensitivity to Hydroclimatic Forcings. Water 2016, 8, 572. [CrossRef]

40. Dalton, J. Experimental Essays on the Constitution of Mixed Gases: On the Force of Steam or Vapour from Water or Other Liquids in Different Temperatures, Both in a Torricelli Vacuum and in Air; on Evaporation; and on Expansion of Gases by Heat. Mem. Liter. Philosoph. Soc. Manch. 1802, 5, 536-602.

41. Penman, H.L.; Keen, B.A. Natural evaporation from open water, bare soil and grass. Proc. R. Soc. Lond. Series, A. Mathemat. Physic. Sci. 1948, 193, 120-145. [CrossRef]

42. Xu, C.Y.; Singh, V.P. Cross Comparison of Empirical Equations for Calculating Potential Evapotranspiration with Data from Switzerland. Water Resour. Manag. 2002, 16, 197-219. [CrossRef]

43. Gombo, D. Surface Water Regime and Resources in Mongolia; Admon Printing: Ulaanbaatar, Mongolia, 2015; pp. 120-156.

44. Magnus, G. Versuche über die Spannkräfte des Wasserdampfs. Ann. Phys. 1844, 137, 225-247. [CrossRef]

45. Matveev, L.T. Fundamentals of General Meteorology: Physics of the Atmosphere; Hydrometeorological press: Leningrad, Russia, 1967.

46. Fifth generation ECMWF atmospheric ReanAlysis of the global climate (ERA5). Available online: https: //cds.climate.copernicus.eu/ (accessed on 14 June 2018).

47. WMO. Guide to Meteorological Instruments and Methods of Observation WMO-No. 8; WMO: Geneva, Switzerland, 2008.

48. Hellman, G. Über die Bewegung der Luft in den untersten Schichten der Atmosphäre. Meteorol Z. 1916, 34, 273-285.

49. Tar, K.; Lázár, I.; Gyarmati, R. Statistical Estimation of the Next Day's Average Wind Speed and Wind Power. In Proceedings of the Perspectives of Renewable Energy in the Danube Region, Budapest, Hungary, 26-27 March 2015; pp. 175-191.

50. Sawaya, K.E.; Olmanson, L.G.; Heinert, N.J.; Brezonik, P.L.; Bauer, M.E. Extending satellite remote sensing to local scales: Land and water resource monitoring using high-resolution imagery. Remote Sens. Environ. 2003, 88, 144-156. [CrossRef]

51. Shang, S.; Shang, S. Simplified Lake Surface Area Method for the Minimum Ecological Water Level of Lakes and Wetlands. Water 2018, 10, 1056. [CrossRef]

52. Fang, J.; Li, G.; Rubinato, M.; Ma, G.; Zhou, J.; Jia, G.; Yu, X.; Wang, H. Analysis of Long-Term Water Level Variations in Qinghai Lake in China. Water 2019, 11, 2136. [CrossRef] 
53. Chebud, Y.A.; Melesse, A.M. Modelling lake stage and water balance of Lake Tana, Ethiopia. Hydrol. Process. 2009, 23, 3534-3544. [CrossRef]

54. Du, Y.; Berndtsson, R.; An, D.; Zhang, L.; Hao, Z.; Yuan, F. Hydrologic Response of Climate Change in the Source Region of the Yangtze River, Based on Water Balance Analysis. Water 2017, 9, 115. [CrossRef]

55. Liao, J.; Shen, G.; Li, Y. Lake variations in response to climate change in the Tibetan Plateau in the past 40 years. Int. J. Digit. Earth 2013, 6, 534-549. [CrossRef]

56. Orkhonselenge, A.; Komatsu, G.; Uuganzaya, M. Middle to late Holocene sedimentation dynamics and paleoclimatic conditions in the Lake Ulaan basin, southern Mongolia. Géomorphol. Relief Process. Environ. 2018, 24, 351-363. [CrossRef]

57. Krapivin, V.F.; Mkrtchyan, F.A.; Rochon, G.L. Hydrological Model for Sustainable Development in the Aral Sea Region. Hydrology 2019, 6, 91. [CrossRef]

58. Chikita, K.A.; Oyagi, H.; Aiyama, T.; Okada, M.; Sakamoto, H.; Itaya, T. Thermal Regime of A Deep Temperate Lake and Its Response to Climate Change: Lake Kuttara, Japan. Hydrology 2018, 5, 17. [CrossRef]

59. Goshime, D.W.; Absi, R.; Ledésert, B. Evaluation and Bias Correction of CHIRP Rainfall Estimate for Rainfall-Runoff Simulation over Lake Ziway Watershed, Ethiopia. Hydrology 2019, 6, 68. [CrossRef]

60. Tao, S.; Fang, J.; Ma, S.; Cai, Q.; Xiong, X.; Tian, D.; Zhao, X.; Fang, L.; Zhang, H.; Zhu, J.; et al. Changes in China's lakes: Climate and human impacts. Nat. Sci. Rev. 2019, 7, 132-140.

(C) 2020 by the authors. Licensee MDPI, Basel, Switzerland. This article is an open access article distributed under the terms and conditions of the Creative Commons Attribution (CC BY) license (http://creativecommons.org/licenses/by/4.0/). 